\title{
AEROMAGNETIC MAP OF PART OF THE COHASSET QUADRANGLE, PLYMOUTH AND NORFOLK COUNTIES, MASSACHUSETTS
}

\author{
GEOPHYSICAL INVESTIGATIONS \\ MAP GP-766
}

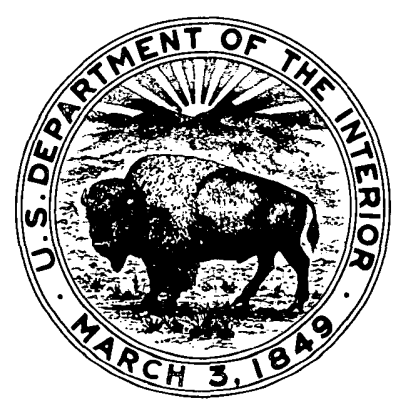

